\title{
The Mechanics of Machining Ultrafine-Grained Grade 2 Ti Processed Severe Plastic Defor- mation
}

\author{
Anastasiya Symonova ${ }^{1}$, Francois Ducobu ${ }^{2}$, Viktorie Weiss ${ }^{3}$ \\ ${ }^{1}$ Department of Mechanical Engineering, Kremenchuk Mykhailo Ostrohradskyi National University. Pershotravheva 20, \\ 39600 Kremenchuk. Ukraine. E-mail: Nsymonova@gmail.com \\ ${ }^{2}$ Department of Machine Design and Production Engineering, University of Mons. Place du Parc 20, B-7000 Mons. Bel- \\ gium. E-mail: francois.ducobu@umons.ac.be \\ ${ }^{3}$ Department of Mechanical Engineering, The Institute of Technology and Business in Ceske Budejovice. Okruzni 10, \\ 37001 Ceske Budejovice. Czech Republic. E-mail: weiss@mail.vstecb.cz
}

Machining of titanium is quite difficult and expensive. Heat generated during the process of cutting does not dissipate quickly, which affects tool life. In the last decade ultrafine-grained (UFG) titanium has emerged as an option for substitution for more expensive titanium alloys. Extreme grain refinement can be readily performed by severe plastic deformation techniques. Grain refinement of a material achieved in this way was shown to change its mechanical and physical properties. In the present study, the microstructure evolution and the shear band formation in chips of coarse grained and UFG titanium machined to different cutting speeds and feeding rates was investigated. It was demonstrated that an improvement in the machinability can be expected for UFG titanium.

Keywords: Ultrafine-grained, Titanium, Machinability, Severe plastic deformtion

\section{Acknowledgement}

The authors would like to thank the Ukraine Mynestry of Education and Science (project no. 0115U002530) for supporting this reseach.

\section{References}

[1] ZHU, Y.T., LOWE, T.C., VALIEV, R.Z., STOLYAROV, V.V., LATYSH, V.V., RAAB, G.I. (2002). Ultrafinegrained titanium for medical implants. US Patent, 6,399,215.

[2] STOLYAROV, V.V., ZHU, Y.T., ALEXANDROV, I.V. et al. (2001). Influence of ECAP routes on the microstructure and properties of pure Ti. In: Materials Science and Engineering, Vol. A299 (1 - 2), pp. 59 - 67. Elsevier. USA.

[3] INYOUNG, K., WON-SIK, J., JONGYOUL, K., KYUNG-TAE, P., DONG, H.S. (2001). Deformation structures of pure Ti produced by equal channel angular pressing. In: Scripta Materialia, Vol. 45, pp. 575 - 581. Elsevier. USA.

[4] MAREK, I., VOJTĚCH, D., MICHALCOVÁ, A., KUBATÍK, T.F. (2015). Preparation and Mechanical Properties of Ultra-High-Strength Nanocrystalline Metals. Manufacturing Technology, Vol. 15, No. 4, pp. 596-600. ISSN $1213-2489$

[5] GERTSMAN, V.Y., BIRRINGER, R., VALIEV, R.Z., GLEITER, H. (1994). On the structure and strength of ultra-fine grained copper produced by several plastic deformation. In: Scripta Metallurgica et Materialia, Vol. 30, pp. 229 - 234. Elsevier. USA.

[6] MOREHEADA, M., HUANGA, Y., HARTWIGB, K.T. (2007). Machinability of ultrafine-grained copper using tungsten carbide and polycrystalline diamond tools. In: International Journal of Machine Tools and Manufacture, Vol. 47, pp. 286 - 293. Elsevier. USA.

[7] LAPOVOK, R., MOLOTNIKOV, A., LEVIN, Y., BANDARANAYAKE, A., ESTRIN, Y. (2012). Machining of coarse grained and ultra fine grained titanium. In: Journal of Materials Science, Vol. 47, pp. 4589 - 4594. Springer. Germany.

[8] SALISHCHEV, G.A., VALIAKHMETOV, R.O., GALEEV, R.M. (1993). Formation of submicrocrystalline structure in the titanium alloys BT8 and influence on mechanical properties. In: Journal of Materials Science, Vol. 28, pp. 2898 - 2902. Springer. Germany.

[9] ISO3685-1977(E). Tool-life testing with single-point turning tools. This standard has been revised by: ISO 3685:1993.9

[10] HORVATH, R., MATYASI, G., DREGELYI-KISS, A. (2015). Examination of the Machinability of Eutectic Aluminium Alloys. Manufacturing Technology, Vol. 15, No. 5, pp. 830-836. ISSN 1213-2489. 
[11] KOMANDURI, R. (1982). Some clarifications on the mechanics of chip formation when machining titanium alloys. In: Wear, Vol. 76, pp. 15 - 34. Elsevier. USA.

[12] BACH, P., POLÁČEK, M., CHVOJKA, P., DROBÍLEK, J. (2014). Dynamic Forces in Unstable Cutting during Turning Operation. Manufacturing Technology, Vol. 14, No. 1, pp. 3-8. ISSN 1213-2489.

[13] CEPOVA, L., SOKOVA, D., MAlOTOVA, S., GAPINSKI, B., CEP, R. (2016). Evaluation of Cutting Forces and Surface Roughness after Machining of Selected Materials. Manufacturing Technology, Vol. 16, No. 1, pp. 4548. ISSN 1213-2489.

[14] HRICOVÁ, J. (2013). Influence of Cutting Tool Material on the Surface Roughness of AlMgSi Aluminium Alloy. Manufacturing Technology, Vol. 13, No. 3, pp. 324-328. ISSN 1213-2489.

[15] EZUGWU, E.O., WANG, Z.M. (1997). Titanium alloys and their machinability a review. In: Journal of Materials Processing Technology, Vol. 68, pp. 262 - 274. Elsevier. USA.

[16] SYMONOVA, A.A., VEREZUB, O.N., SYCHEVA, A.A., VEREZUB, N.V., HAVIN, V.L., KAPTAY, G. (2012). Surface grain coarsening and surface during machining of ultra-grained titanium. In: Journal of Mining and Metallurgy. Sec. B, Vol. 48, pp. 378 - 389. University of Belgrade. Serbia.

[17] SUTTER, G., LIST, G. (2013). Very high speed cutting of Ti-6Al-4V titanium alloy-change in morphology and mechanism of chip formation. In: International Journal of Machine Tools and Manufacture, Vol. 66, pp. 37 - 43. Elsevier. USA.

[18] ZWICKER, U. (1974). Titan und Titanlegierungen, pp. 26 - 63. Berlin: Springer Verlag. H.N.I.

[19] VALIEV, R.Z. (2004). Nanostructuring of Metals by Several Plastic Deformation for Advanced Properties. In: Nature Materials, Vol. 3, pp. 511 - 516. Nature Publishing Group. Great Britain. 